$\underline{\text { Iranian Journal of Pathology | ISSN: 2345-3656 }}$

\title{
Ovarian Small Cell Carcinoma: A Rare Case Report and Review of Literature
}

\author{
Savita Agarwal ${ }^{1}$, Pinki Pandey ${ }^{1}$, Megha Ralli $^{1 *}$, Shruti Singh ${ }^{1}$ \\ 1. Dept. of Pathology, UP University of Medical Sciences, Saifai, Etawah, India
}

\begin{tabular}{|c|c|}
\hline KEYWORDS & ABSTRACT \\
\hline $\begin{array}{l}\text { Small Cell Carcinoma } \\
\text { Immunohistochemistry }\end{array}$ & $\begin{array}{l}\text { Ovarian small cell carcinoma is a rare and highly malignant tumor with poor } \\
\text { prognosis. It usually presents in younger females with features of hypercalcemia. The }\end{array}$ \\
\hline Ovary & $\begin{array}{l}\text { exact histogenesis of the tumor is unclear and it may present as an undifferentiated } \\
\text { tumor. In such cases, immunohistochemistry (IHC) plays an important role to }\end{array}$ \\
\hline Article Info & \\
\hline $\begin{array}{l}\text { Received } 19 \text { Oct 2016; } \\
\text { Accepted } 22 \text { Apr 2017; }\end{array}$ & $\begin{array}{l}\text { radical surgery followed by adjuvant therapy in advanced stages. The current report } \\
\text { was a rare case of small cell carcinoma of ovary presenting no symptoms of } \\
\text { hypercalcemia diagnosed on histopathological examination and IHC findings. }\end{array}$ \\
\hline
\end{tabular}

Corresponding information: Dr. Megha Ralli, 30/32 West Patel Nagar, New Delhi-110008., Email address: drmegharalli@gmail.com

Copyright $\odot$ ( 2017, IRANIAN JOURNAL OF PATHOLOGY. This is an open-access article distributed under the terms of the Creative Commons Attributionnoncommercial 4.0 International License which permits copy and redistribute the material just in noncommercial usages, provided the original work is properly cited.

\section{Introduction}

Small cell carcinoma of ovary is a rare malignant tumor with only 300 cases described in the literature till date (1). It is generally described as a form of undifferentiated ovarian carcinoma in young females below 40 years old and only $<1 \%$ of the cases occur in children (2). The youngest patient reported to date is 14 months (3).In twothirds of the cases, this tumor is associated with hypercalcemia and exact pathophysiology of hypercalcemia is unknown; however, in some cases it may be related to secretion of PTH-RP (parathyroid hormone-related protein), as observed on immunohistochemistry (IHC) analyses (4).Because of the rarity of the disease, there are no evidence-based treatment recommendations and these cases have poor prognosis even when diagnosed at early stage (5). Patients with stage I disease have an average survival of 5.7 years (5).The current case of ovarian undifferentiated tumor, presenting no features of hypercalcemia, was diagnosed and reported as small cell carcinoma on histopathological examination and was confirmed on IHC.

\section{Case Report}

A 45-year-old female presented with two weeks history of nausea, vomiting, abdominal pain, and bloating. There was no significant medical and menstrual history. There were no signs and symptoms of hypercalcemia. On general physical examination, the patient was anemic and thinly built. On palpation abdomen was soft and tender and there was a palpable mass in left lower quadrant. Pelvic examination revealed 2-to4-weeksize uterus and a palpable left adnexal mass. Ultrasound and computed tomography (CT) scan showed a mass measuring $27 \times 17 \times 12 \mathrm{~cm}$ arising from left adnexa. Subsequently, the patient underwent a planned exploratory laparotomy, total abdominal hysterectomy, bilateral salpingoopherectomy, and omentectomy. Specimen was, then, submitted for histopathological examinations. On gross examination, uterus and cervix measured 10x6x3 cm. On cutting, endometrial cavity was patent and endometrial thickness measured $0.4 \mathrm{~cm}$. My ometrium showed three intramural and one sub serosal fibroids varying in diameter from 1.5 to $5 \mathrm{~cm}$. Right fallopian tube and ovary were unremarkable. Left ovary was enlarged and measured 27x17x12 cm. The ovarian capsule was intact and external surface 
was bosselated (Figure 1a). Cut section of tumor revealed solid and cystic areas filled with yellowish, watery, and hemorrhagic fluid. Cysts varied in diameter from 0.5 to $18 \mathrm{~cm}$ with wall thickness varying from 0.2 to $0.8 \mathrm{~cm}$. Intervening solid grey-white areas had variegated appearance with yellowish friable necrotic areas; at places, there were dark brown hemorrhagic areas along with foci of shiny mucoid areas (Figure 1b).

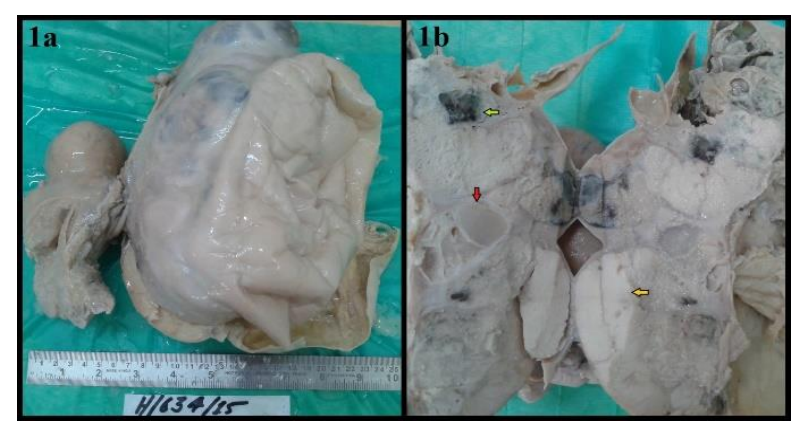

Fig 1.a) Uterus and cervix measuring 10x6x3 cm.Left ovary is enlarged and measuring $27 \times 17 \times 12 \mathrm{~cm}$. The ovarian capsule is intact and external surface was bosselated.

b) Cut section of tumor showing solid and cystic areas filled with yellowish, watery, and hemorrhagic fluid.

Microscopically, the tumor cells were arranged in solid nests and focally forming rosettes along with large central areas of necrosis within the nests (Figure 2a). The tumor cells were small with high nucleocytoplasmic ratio mildly pleomorphic nuclei, granular chromatin, inconspicuous nucleoli, and scant cytoplasm (Figure 2b).

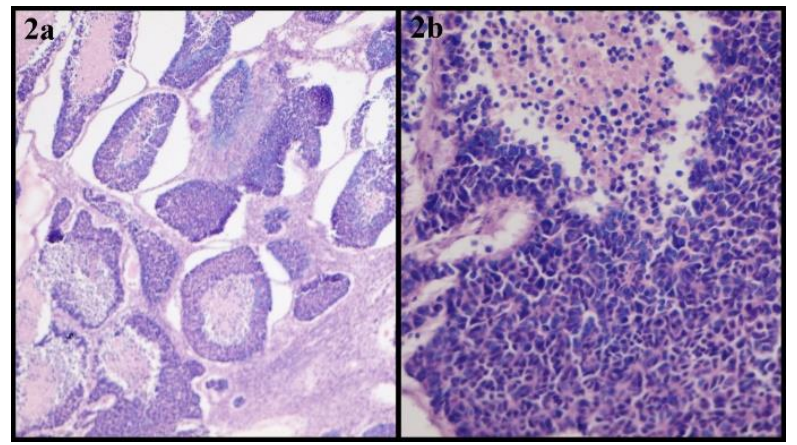

Fig 2. a)Tumor cells arranged in solid nests and focally forming rosettes along with large central areas of necrosis within the nests (H\&E,100X).

b) Thesetumor cells are small with high nucleocytoplasmic ratio mildly pleomorphic nuclei, granular chromatin, inconspicuous nucleoli, and scant cytoplasm (H\&E, 400X).
Mitotic count was high (>5/10hpf). Based on the morphological features, possibilities of small cell carcinoma, granulosa cell tumor, and undifferentiated carcinoma were considered. An IHC panel for pan cytokeratin (Pan CK), synaptophysin, chromogranin, nonspecific esterase (NSE), inhibin, cluster of differentiation (CD) 99, Thyroid transcription factor-1 (TTF-1), and epithelial membrane antigen (EMA) was put up. Present case showed positivity for Pan CK, synaptophysin, NSE, and EMA, and focal positivity for chromogranin (Figure 3).

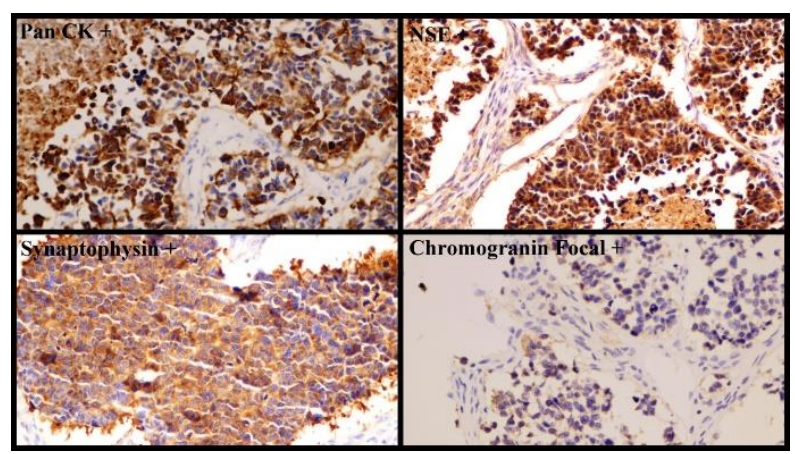

Fig 3. Immunohistochemically profile of tumor cells: Pan CK, NSE;synaptophysin: strongly positive; chromogranin: focally positive

Tumor cells were negative for inhibin, TTF-1, and CD99. On the basis of histopathological and IHC findings, diagnosis of small cell neuroendocrine carcinoma was made. There was no evidence of metastasis in the right ovary, bilateral fallopian tubes, and omentum. Therefore, she was diagnosed with ovarian small cell carcinoma stage IA.

Then, radical surgery was performed to remove the tumor; patient was treated with cycles of bleomycin, etoposide, and cisplatin (BEP) chemotherapy. After completion of six cycles, CT scan was performed and there was no evidence of recurrence in the patient. Hormone replacement therapy was started on the patient, but, she is not followed up.

\section{Discussion}

Small cell carcinoma of ovary is a rare malignant tumor first described by Dickersin et al., in 1982 (6). It was briefly mentioned by Scully in 1979 (7).Following it many cases were reported, 
including the largest series comprising of 150 cases reported by Young et al. in 1994 (2). Approximately $66 \%$ of patients in the series also had hypercalcemia, and its associated manifestations were fatigue, lethargy, polydipsia, and polyuria. Some studies serologically documented the presence of parathyroid hormone (PTH)-related protein (PTHrp), but the ectopic production of PTH was rarely reported (5).However, clinical features of hypercalcemia were not observed in the current case and serum calcium levels were also within the normal limits.

Small cell carcinoma of the ovary is an undifferentiated neoplasm and its histogenesis is not clear. The origin of tumor cells is epithelial, germinal, or mesenchymal, which is not clearly determined (8). The initial germ cell origin is described; however, the subsequent studies based on electron microscopy did not support this theory and instead suggested epithelial origin $(9,10)$. An animal model was also used to investigate the histogenesis, but it could not find a histogenesis relationship with either the germ cell tumor or epithelial tumor of the ovary (5). In terms of oncogenesis, approximately $80 \%$ of small cell carcinomas of the ovary overproduce $\mathrm{P} 53$ protein, suggesting that a p53mutationmay be an underlying cause (5).

Histologically, two variants are described: one is similar to small cell carcinoma of lung, and the other one is characterized by the presence of large cell component (8).The current case showed small cell pattern only and no large cell component was found. The most common microscopic pattern is a sheet-like arrangement of small, closely packed epithelial cells. Large cell components usually represent a minor to moderate component of the tumor, but rarely the predominant or even exclusive component can be observed, and they are described as "large cell variant" of small cell carcinoma (2). The immunohistochemically staining pattern typical for tumor cells is positive for epithelial markers(cytokeratin and EMA), INI1, (Wilms tumor)WT-1, calretinin, CD10, and p53 (11).It may express vimentin and NSE.A single case of small cell carcinoma of the ovary expressing CD34 was described in the literature (12). The differential diagnosis was broad and included adult and juvenile granulosa cell tumor, primitive germ cell tumor, malignant lymphoma, primitive neuroectodermal tumor, neuroblastoma, desmoplastic small round cell tumor, small cell carcinoma (pulmonary type), and metastatic small cell carcinoma (13).IHC becomes essential for definitive identification of the tumor.

In rare cases exhibiting rhabdoid cytomorphology, the tumor cells were very similar to malignant rhabdoid tumor(MRT) (14).Molecular genetic studies showed that small cell carcinoma (hypercalcemic type) contained alterations in genes SMARCB1 or SMARCA4 also observed in MRTs; therefore, some authors renamed it as 'MRT of the ovary' (15).

It is usually unilateral (99\%), but bilateral familial cases are reported (13). Currently, there is no definite treatment for small cell carcinoma of the ovary. Although in the early stage when the tumor is unilateral, radical surgery in order to remove the uterus is done. But, it is desirable to preserve the fertility in young patients. Therefore, the conservative surgical treatment sparing the ovary and uterus is recommended in the early stages (16).For the higher stages or recurrent tumors, chemotherapy, radiotherapy, or both may improve survival (5).According to the study conducted by Young et al., favorable prognostic factors of small cell carcinoma include the localized stage of tumor, tumor size less than 10 $\mathrm{cm}$, patient age above 30 years, and absence of large cells (2). However, tumor stage is the most important prognostic factor. The overall survival rate is about $10 \%$ and reaches $30 \%$ when the tumor is stage IA (16). The overall prognosis of this tumor is poor $(2,8)$.

\section{Conclusion}

The current report presented a case of small cell carcinoma of ovary in a 45-year-old patient. The case was $>30$ years old, with tumor size of $27 \mathrm{~cm}$, absence of large cells histologically, and absence of tumor metastasis. It was a rare tumor of high malignant nature and poor prognosis. With limited number of cases reported, there are no definite treatment guidelines available. Therapy is primarily surgical, with adjuvant treatment reserved for the advanced-stage disease. 


\section{References}

1. Kapoun M, Bouda J, Presl J, Vlasak P, Slunecko R. Agressive small cell carcinoma of the ovary, hypercalcemic type, surgery and oncological treatment: case report. CeskaGynekol 2015;80:218-21.

2. Young RH, Oliva E, Scully RE. Small cell carcinoma of the ovary, hypercalcemic type: a clinicopathological analysis of 150 cases. American Journal of Surgical Pathology 1994;18:1102-16.

3. Florell SR,Bruggers CS, Matlak M, Young RH, Lowichik A. Ovarian small cell carcinoma of the hypercalcemic type in a 14 month old: the youngest reported case.Medical and Pediatric Oncology 1999;32:304-7.

4. Matias-Guiu X, Prat J, Young RH et al.Human parathyroid hormone-related protein in ovarian small cell carcinoma: an immunohistochemical study. Cancer 1994;73:1878-81.

5. Chen L, Dinh TA, Haque A. Small cell carcinoma of the ovary with hypercalcemia and ectopic parathyroid hormone production. Arch Pathol Lab Med. 2005;129:531-3.

6. Dickersin GR, Kline IW, Scully RE: Small cell carcinoma of the ovary with hypercalcemia: a report of eleven cases. Cancer 1982;49:188-197.

7. Scully R: Tumors of the Ovary and Maldeveloped Gonads. Washington, Armed Forces Institute of Pathology, 1979.

8. Origoni M, Bergamini A, Pella F, Ottolina J, Giorgione V, Prato DD et al. Small Cell Carcinoma of the Ovary: Report of Three Cases of a Poor Prognosis Disease. J Med Cases.2013;4(3):189-92.
9. Ulbright TM, Roth LM, Stehman FB. Poorly differentiated (small cell) carcinoma of the ovary in young women. Evidence supportingg a germ cell origin. Human Pathology 1987;18:175-84.

10. McMahn JT and Hart W. Ultrastructural analysis of small cell carcinomas of the ovary. American Journal of Clinical Pathology 1988;90:523-9.

11. Bakhru A, Liu JR, Lagstein A. A case of small cell carcinoma of the ovary hypercalcemic variant in a teenager. GynecOncol Rep 2012;2:139-42.

12. Inadome $\mathrm{Y}$, Shibata $\mathrm{T}$, Suzuki K, Tsugata M, Shimabukuro K, Noguchi M. Hypercalcemic-type ovarian small cell carcinoma with unique CD34 expression. PathologyInternational 2009;59:766-8.

13. Rovithi M, Pallis AG, Kalykaki A, Lagoudaki E, Giannikaki L, Stathopoulos EN et al. Small cell ovarian cancer in adolescents: Report oftwo cases and review of the literature. Case Rep Med 2011; Article ID 749516. doi:10.1155/2011/749516.

14. Kascak P, Zamecnik M, Bystricky B. Small cell carcinoma of ovary (hypercalcemic type): Malignant Rhabdoid tumor. Case Rep Oncol 2016;9:305-11.

15. Foulkes WD, Clarke BA, Hasselblatt M, Majewski J, Albrecht S, McCluggage WG: No small surprise - small cell carcinoma of the ovary, hypercalcaemic type, is a malignant rhabdoidtumour. J Pathol 2014;233:209-214.

16.Zaied S, Gharbi O, Zayene A, Rjiba R, Hadhri R, Hadded A et al. Small Cell Carcinoma of the Ovary of Hypercalcemic Type: ACase Report. Case Rep Oncol Med 2012; Article ID 461873,

\section{How to Cite This Article}

Agarwal S, Ralli M, Pandey P, Singh, S. Ovarian Small Cell Carcinoma: A Rare Case Report and Review of Literature. Iran J Pathol. 2018; 13(1): 99-102. 